\title{
Effect of 8 hours of hyperinsulinaemia on haemostatic parameters in healthy man
}

\author{
G. Mauricio-Leguizamo ${ }^{1}$, L.Heinemann ${ }^{1}$, R. E. Scharf ${ }^{2}$ and M. Berger ${ }^{1}$ \\ ${ }^{1}$ Department of Nutrition and Metabolism, and \\ ${ }^{2}$ Department of Haematology, Oncology and Clinical Immunology, Heinrich-Heine-Universität Düsseldorf, Düsseldorf, FRG
}

\begin{abstract}
Summary. The role of variations in plasma insulin concentrations as a factor possibly involved in abnormalities of haemostatic functions, and (or) the development of arterial disease, has been the subject of controversy. This study examines the "in vivo" effect of hyperinsulinaemia on haemostatic parameters in seven healthy men. Two studies were carried out in random order: (a) Hyperinsulinaemia study. Human insulin was infused by a calibrated infusion pump $\left(0.7 \mathrm{mU} \mathrm{kg}^{-1} \mathrm{~min}^{-1}\right.$, for $8 \mathrm{~h}$ ) during a euglycaemic glucose clamp, and (b) Control study $0.15 \mathrm{mmol} / 1 \mathrm{NaCl}$ solution was infused over $8 \mathrm{~h}$. Plasma epinephrine and norepinephrine concentrations remained constant throughout the studies. Mean insulin levels during the hyperinsulinaemia study were $46.2 \pm 1.6 \mu \mathrm{U} / \mathrm{ml}$, i.e. ap-
\end{abstract}

proximately eightfold higher than those at baseline, whereas plasma glucose levels remained constant at $4.9 \pm 0.1 \mathrm{mmol} / 1$. During the control study, mean insulinaemia was $5.0 \pm$ $0.9 \mu \mathrm{U} / \mathrm{ml}$, and plasma glucose $5.2 \pm 0.1 \mathrm{mmol} / 1$. No statistically significant changes were observed during, or after insulin or $0.15 \mathrm{mmol} / 1 \mathrm{NaCl}$ infusions with regard to platelet parameters, blood coagulation, and coagulation inhibitors. These data suggest that abnormalities of the haemostatic function described during insulin-induced hypoglycaemia or in hyperinsulinaemic patients are not due to a direct action of insulin.

Key words: Haemostasis, hyperinsulinaemia, platelet function.
Arterial disease affecting both large and small calibre vessels is responsible for the major causes of the increased morbidity and mortality in diabetic patients. Considerable efforts have been made to identify the role of the haemostatic system as a factor possibly involved in the pathogenesis of vascular complications in diabetic subjects during hyperglycaemic, normoglycaemic, and hypoglycaemic conditions [1-4]. Multiple abnormalities of haemostatic functions during insulininduced hypoglycaemia have been described; including increased platelet aggregation, alterations of coagulation factors and abnormal fibrinolytic activity [5-12]. These haemostatic dysfunctions have either been attributed to acute hyperinsulinaemia or the secondary increases of counter regulatory hormone concentrations $[5,7,11]$.

On the other hand, several studies have shown that obesity is associated both with alterations of haemostatic functions and hyperinsulinaemia [13]: In addition, it has been shown that patients with hypertension are hyperinsulinaemic, independent of concomitant obesity or antihypertensive medication, and present with haemostatic abnormalities $[14,15]$. Recent reports have suggested that hyperinsulinaemia may be a possible risk factor for macrovascular disease in diabetes mellitus, and that hyperinsulinaemia may relate to cardiovascular disease independent of other risk factors [16, 17].

The role of variation in plasma insulin concentration as a factor possibly involved in abnormalities of haemostatic function and (or) the development of arterial disease is unknown. The purpose of the present study was to investigate the "in vivo" effect of hyperinsulinaemia on haemostatic parameters (platelet function, blood coagulation and fibrinolytic activity) in healthy subjects by means of the hyperinsulinaemiceuglycaemic glucose clamp technique.

\section{Subjects and methods}

\section{Subjects}

Studies were carried out in seven healthy male volunteers ranging in age from $18-32$ years with a body mass index of $22.5 \pm 1.3 \mathrm{~kg} / \mathrm{m}^{2}$ (mean $\pm S D$ ), who did not take aspirin or any other medication during the ten days prior to the studies. All subjects were non-smokers, and there was no family history of diabetes mellitus. The subjects were given a detailed oral and written description of the study and their written consent was obtained. The study was carried out according to the principles of the Declaration of Helsinki [18]. 


\section{Study protocol}

We performed two different studies in random order, separated by an interval of at least two weeks: an 8-h infusion of human regular insulin (Hyperinsulinaemia study), or infusion of $0.15 \mathrm{mmol} / \mathrm{l} \mathrm{NaCl}$ (Control study). All studies were performed at 08.00 hours after an overnight fast, and following a rest period of $30 \mathrm{~min}$ after the subjects had arrived in the laboratory.

Hyperinsulinaemia study. The volunteers were, in a resting position, connected to a Biostator (Glucose Controlled Insulin Infusion System, Life Science Instruments, Miles Laboratories Inc, Elkhart, Ind, USA) which has been previously described [19]. Briefly, it consists of the three modules: an on-line glucose analyser, a multichannel infusion system, and a computer-controller module. The glucose analyser allows continuous blood withdrawal, and the infusion system allows precise administration of a glucose solution. A double lumen catheter for continuous blood glucose determination was inserted retrogradely into a forearm vein. The hand was placed in a heated chamber $\left(55^{\circ} \mathrm{C}\right)$ for the duration of the study. A second polyethylene catheter was inserted into an antecubital vein for blood sampling. Human insulin (Actrapid HM, Novo Laboratories, Copenhagen, Denmark) in albumin $0.15 \mathrm{mmol} / 1 \mathrm{NaCl}$ dilution (1:20) was infused by a calibrated infusion pump (Harvard Apparatus, South Natick, Mass, USA) at an infusion rate of $0.7 \mathrm{mU} \mathrm{kg}^{-1} \mathrm{~min}^{-1}$, for $8 \mathrm{~h}$ (aimed at elevating plasma insulin levels to $50 \mu \mathrm{U} / \mathrm{ml}$ ) into an antecubital vein of the contralateral arm. The euglycaemic glucose clamp was continued for an additional $2 \mathrm{~h}$ after the termination of the insulin infusion. The subjects were kept fasting during the experiments.

The basal blood samples for insulin, glucose, epinephrine, norepinephrine, non esterified fatty acids (NEFA), platelet count, $\beta$ thromboglobulin ( $\beta T G$ ), platelet factor 4 (PF 4), prothrombin time (PT), activated partial thromboplastin time (aPTT), fibrinogen, fibrinopeptide A (FPA), factor VIII coagulant activity (F VIII:C), plasminogen, protein $C$ activity, antithrombin III activity (AT III), and $\alpha 2$ antiplasmin ( $\alpha 2-\mathrm{AP})$ measurements were obtained before the start of the insulin infusion. Seven separate venipunctures in forearm veins were performed at the following times: $1,2,4,6,8,9$, and $10 \mathrm{~h}$, throughout each study.

Control study. A polyethylene catheter was inserted into an antecubital vein for an 8 -h infusion of $0.15 \mathrm{mmol} / 1 \mathrm{NaCl}$ solution by Infusomat (B. Braun, Melsungen, FRG) at an infusion rate of $125 \mathrm{ml} / \mathrm{h}$. The basal blood samples were obtained before the start of the $\mathrm{NaCl}$ infusion. Venipunctures for blood samples were performed at the same times as described above for the hyperinsulinaemia study.

Preparation of plasma samples. Blood samples were withdrawn through a 21 gauge siliconized "butterfly" needle (Abbott, Sligo, IreIand). Immediately after venipuncture, the tourniquet was released, and blood was withdrawn into a $5 \mathrm{ml}$ polypropylene syringe (containing the respective and adequate amount of anti-coagulant solution), and transferred immediately to pre-cooled tubes placed in melting ice. For the plasma $\beta T G$ and PF 4 assays $2.7 \mathrm{ml}$ blood was collected into a mixture of $0.1 \mathrm{ml} \mathrm{Na}{ }_{2}$ EDTA $0.27 \mathrm{~mol} / 1,0.1 \mathrm{ml}$ theophylline $30 \mathrm{mmol} / 1,0.1 \mathrm{ml} \mathrm{PGE} 100 \mu \mathrm{mol} / 1$ and $30 \mu \mathrm{l}$ indomethacin $800 \mu \mathrm{mol} / 1$. For the FPA assay $4.5 \mathrm{ml}$ blood was collected into $0.5 \mathrm{ml}$ of a mixture of heparin $1000 \mathrm{U} / \mathrm{ml}$ and aprotinin $1000 \mathrm{U} / \mathrm{ml}$ in a buffer containing $\mathrm{NaCl} 0.13 \mathrm{~mol} / \mathrm{l}$. For the determination of coagulation, fibrinolytic and inhibitory parameters nine volumes of blood were collected into one volume of trisodium citrate $0.11 \mathrm{~mol} / 1$ [20]. Syringes for blood collection were used in the following chronological order: (a) BTG and PF4, (b) FPA, (c) citrated blood, (d) glucose and chemistry assays, and (e) insulin and catecholamines. Platelet rich plasma (PRP) and platelet poor plasma (PPP) were obtained by centrifugation at $150 \mathrm{~g}$ for $15 \mathrm{~min}$ or at $1500 \mathrm{~g}$ for $30 \mathrm{~min}$ at $4^{\circ} \mathrm{C}$, respectively. Citrated blood was centrifuged at $2000 \mathrm{~g}$ for $30 \mathrm{~min}$ at room temperature. The plasma was carefully separated and stored frozen at $-20^{\circ} \mathrm{C}$ until the day of assay. Each determination was made in duplicate, the mean values being taken as the final result. Platelet count, PT, aPTT, and F VIII:C were determined immediately after blood processing.

\section{Analytical methods}

Plasma and intraplatelet levels of $\beta$ TG and PF4 were determined by radioimmunoassay kits from the Radiochemical Centre (Amersham Buchler, Braunschweig, FRG) and Abbott Laboratories (WiesbadenDelkenheim, FRG) respectively; details of the methods have been previously described $[20,21]$. For determination of intraplatelet $\beta T G$ and PF4 content platelets were lysed by adding $20 \mu \mathrm{l}$ of $10 \%$ volume/volume Triton X-100 to $180 \mu 1$ of PRP. Blood platelet counts were performed in PRP using a Thrombocounter (Coulter Electronics, Hialeah, Fla., USA). PT and aPT were assayed by one-stage technique using an automated clot detection system and reagents purchased from Boehringer Mannheim (Mannheim, FRG). Plasma fibrinogen was measured according to Clauss [22]. F VIII:C was assayed by one-stage technique based on the normalization of the clotting time of specific factor deficient plasmas [23]. FPA was measured by radioimmunoassay using the RIA-Quant FPA kits (Mallinckrodt Diagnostica, Dietzenbach, FRG) [24]. Protein C activity was determined photometrically by the chromogenic method using BCP 300 (pGlu-Pro-Arg-MNA [2-Methoxinitroaniline]) as substrate (Behringwerke AG, Marburg, FRG) [25]. AT III was evaluated by an antithrombin (heparin cofactor) assay (KabiVitrum AB, Stockholm, Sweden) [26]. Plasminogen was measured using an excess of streptokinase as described by Gram and Jespersen [27] (KabiVitrum AB, Stockholm, Sweden). $\alpha_{2}$-AP was assayed by a chromogenic method (KabiVitrum AB, Stockholm, Sweden) [28]. Plasma glucose was monitored by the glucose oxidase method (Glucose Analyzer, Beckman In-

Table 1. Plasma concentrations of free insulin, glucose, non esterified fatty acid (NEFA) and catecholamines at baseline, during and after the hyperinsulinaemia (A) and control study (B) in seven healthy subjects

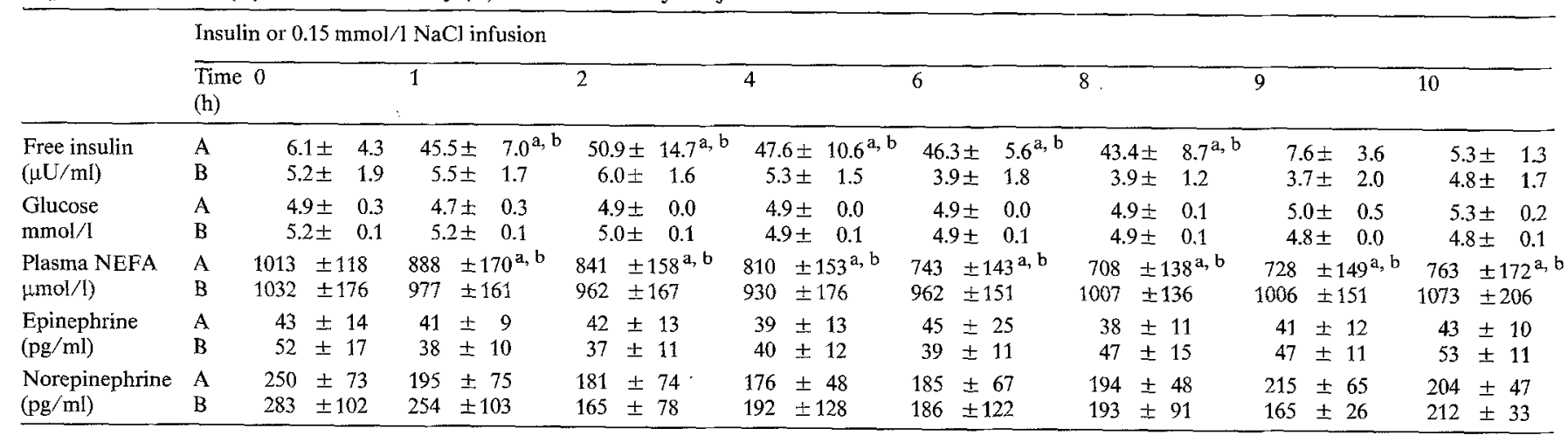

${ }^{\text {a }} p<0.01$ vs baseline at $0 \mathrm{~h} ;{ }^{b} p<0.01$ vs respective value during the control study (B) 
Table 2. Effect of insulin (A) and $0.15 \mathrm{mmol} / 1 \mathrm{NaCl}$ infusion (B) on platelet parameters in seven healthy subjects

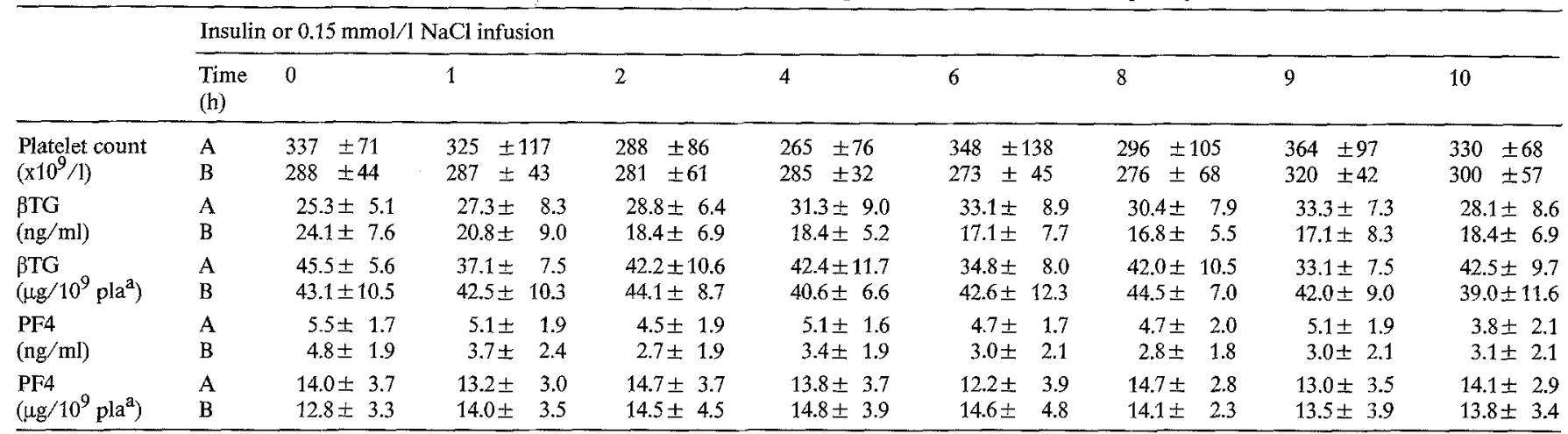

a Platelet $\beta \mathrm{TG}=\beta$-Thromboglobulin, PF4= platelet factor 4

Table 3. Effect of insulin (A) and $0.15 \mathrm{mmol} / 1 \mathrm{NaCl}$ infusion (B) on blood coagulation, fibrinolytic and inhibitory parameters in seven healthy subjects

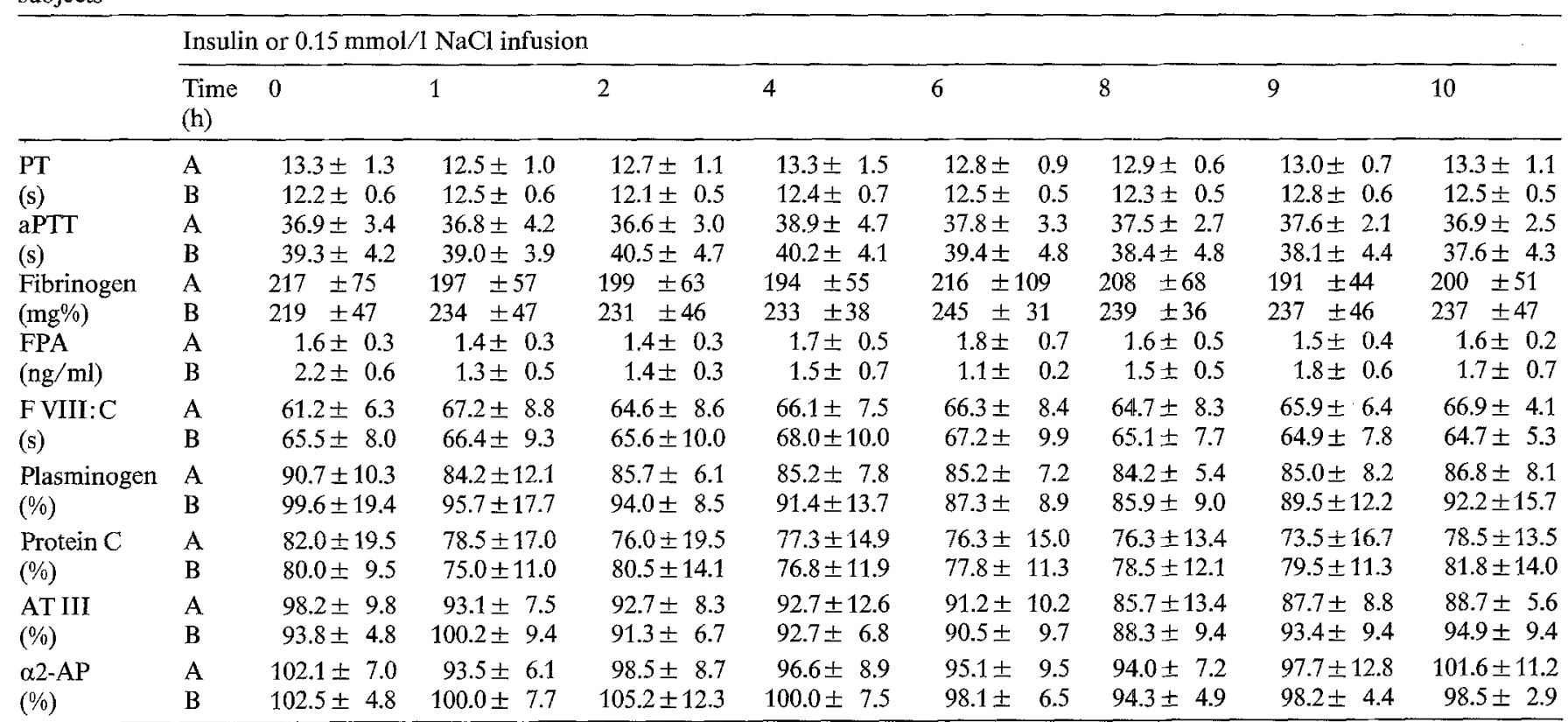

PT $=$ prothrombin time, aPTT = activated partial thromboplastin time, FPA= fibrinopeptide A, FVIII:C = factor VIII coagulant activity, AT III $=$ antithrombin III activity, $\alpha_{2}-\mathrm{AP}=\alpha_{2}$-antiplasmin

struments, Fullerton, Calif., USA). Insulin was measured with a commercially available double antibody radioimmunoassay (Phadebas Co., Uppsala, Sweden). The inter-assay coefficient of variation of the insulin assay was $10.3 \%$ at $4 \mu \mathrm{U} / \mathrm{ml}$ and $5.1 \%$ at values greataer $30 \mu \mathrm{U} / \mathrm{ml}$. The intra-assay coefficient of variation ranged between 2.1 and 3.1\% for low and high insulin concentrations. The polyethylene glycol extraction for plasma free insulin was performed immediately after blood withdrawal, i.e. after centrifugation of $3 \mathrm{ml}$ blood, $1.0 \mathrm{ml}$ plasma and $1.0 \mathrm{ml}$ of added $30 \%$ polyethylene glycol (mol 6000) were thoroughly mixed. After centrifugation the supernatant was stored at $-20^{\circ} \mathrm{C}$. Plasma catecholamine and NEFA concentrations were assayed as described earlier by Kemmer et al. [29].

\section{Statistical analysis}

All data are expressed as mean $\pm \mathrm{SD}$. Their statistical significance was evaluated by two-tailed paried Student's $t$-test.

\section{Results}

Circulating levels of free insulin, glucose, NEFA and catecholamines before, during and after insulin or $0.15 \mathrm{mmol} / 1 \mathrm{NaCl}$ infusion are presented in Table 1.

Plasma insulin. The fasting levels of free insulin were similar in both studies: $6.1 \pm 4.3 \mu \mathrm{U} / \mathrm{ml}$ (hyperinsulinaemia study), and $5.2 \pm 1.9 \mu \mathrm{U} / \mathrm{ml}$ (control study). The insulin infusion during the hyperinsulinaemia study induced an increase of plasma insulin concentrations from basal values to mean steady-state levels of $46.2 \pm 1.6 \mu \mathrm{U} / \mathrm{ml}$, i.e. approximately eightfold higher than those at baseline. After the end of the insulin infusion, insulin levels returned toward the basal values. In the control study, plasma insulin concentrations re- 
mained constant during the $0.15 \mathrm{mmol} / 1 \mathrm{NaCl}$ infusion at $5.0 \pm 0.9 \mu \mathrm{U} / \mathrm{ml}$.

Plasma glucose. In the hyperinsulinaemia study, mean plasma glucose levels were $4.9 \pm 0.3 \mathrm{mmol} / 1$ before induction of $8-\mathrm{h}$ hyperinsulinaemia and remained at $4.9 \pm 0.1 \mathrm{mmol} / 1$ during the steady-state period of insulin infusion. The mean basal plasma glucose concentrations in the control study were $5.2 \pm 0.1 \mathrm{mmol} / 1$ and did not change throughout the studies. No significant differences were observed between the two studies. The total amount of glucose infused during the hyperinsulinaemia study was $366 \pm 41 \mathrm{~g}$.

Plasma free fatty acids. The fasting NEFA concentrations were not different in both studies. During the 8-h insulin infusion period, plasma NEFA levels decreased progressively from a basal concentration of $1013 \pm$ $118 \mu \mathrm{mol} / 1$ to $708 \pm 138 \mu \mathrm{mol} / 1$. In contrast, during $0.15 \mathrm{mmol} / 1 \mathrm{NaCl}$ infusion, plasma NEFA levels remained constant throughout the studies.

Plasma catecholamines. No changes were seen between hyperinsulinaemia and control studies with regard to plasma epinephrine or norepinephrine concentrations.

Haemostatic parameters. The results for platelet parameters are shown in Table 2 . No significant changes in platelet count or mean plasma levels of platelet specific proteins were observed throughout hyperinsulinaemia and control studies. The same was true for intraplatelet concentrations of alpha-agranular constituents that remained unchanged, both in the hyperinsulinaemia study and the control study. The plasma parameters of blood coagulation, fibrinolytic and inhibitory activity are shown in Table 3 . No differences were observed in PT, aPTT, fibrinogen, FPA, F VIII: C, plasminogen, protein $\mathrm{C}$, AT III, or $\alpha_{2}$-AP between the hyperinsulinaemia and the control studies.

\section{Discussion}

In this study the effects of plasma insulin on various factors involved in normal haemostatic function were investigated during hyperinsulinaemic-euglycaemic clamp conditions compared to a normoinsulinaemiceuglycaemic control study. The expected decrease in plasma NEFA levels during the infusion of exogenous insulin demonstrated the biological effectiveness of the obtained insulin levels $(\approx 50 \mu \mathrm{U} / \mathrm{ml})$, whilst blood glucose was clamped at $5.0 \mathrm{mmol} / 1[30]$.

Varying concentrations in plasma insulin levels that may be involved in abnormalities of haemostatic functions have been the subject of controversy. Recently, it has been suggested that insulin has direct effects on the endothelial cell and erythrocyte functions [31]. In the present study haemostatic parameters of seven healthy subjects were evaluated before, during and after an 8-h period of sustained hyperinsulinaemia. No significant changes between hyperinsulinaemia and control studies were observed with regard to platelet parameters, blood coagulation, and coagulation inhibitors. Trovati et al. described that insulin-induced hypoglycaemia influences various platelet functions [5]. It has been suggested that epinephrine may be responsible for the hypoglycaemia-induced increase of platelet aggregation and release of platelet specific proteins [5, 32]. Likewise, Corrall et al. noted that the rise in F VIII:C following hypoglycaemia is mediated via an adrenergic mechanism [7]. Based on our hyperinsulinaemia study where the haemostatic parameters and plasma catecholamine concentrations remained constant in all subjects, it is suggested that haemostatic changes occurring in response to insulin-induced hypoglycaemia in normal and diabetic subjects result from the secretion of counter regulatory hormones, which are part of the physiological response to hypoglycaemia, but not due to any direct action of insulin. Another area of controversy concerns the association of hyperinsulinaemia with fibrinolytic alterations as a factor possibly related to the development of macrovascular disease in diabetes mellitus and coronary heart disease in hyperinsulinaemic patients. With respect to the fibrinolytic system, no conclusions can be drawn from this study since we did not evaluate euglobulin clot lysis time, tissue-type plasminogen activator, or plasminogen activator inhibitors. In this study, $8 \mathrm{~h}$ of sustained hyperinsulinaemia in normoglycaemic subjects did not cause any changes of the haemostatic parameters evaluated. These data suggest that abnormalities of haemostatic functions described in hyperinsulinaemic patients are not due to hyperinsulinaemia per se. However, possible effects of more prolonged hyperinsulinaemia when associated with other atherosclerosis risk factors (such as hypertension or lipoprotein abnormalities) with regard to the development of atherogenesis and (or) thrombosis cannot be excluded on the basis of this study.

Acknowledgments. The excellent technical assistance of S.Zimmermann, F. Grau, C. Reetz, H. Kemmer and co-operation and helpful advice of A. A. R. Starke MD are gratefully acknowledged. This study was supported by the Peter Klöckner Foundation, Duisburg, FRG (grants to Prof. M. Berger).

\section{References}

1. Osterman H, van de Loo J (1986) Factors of the hemostatic system in diabetic patients. A survey of controlled studies. Haemostasis 16: $386-416$

2. Paton RC (1981) Haemostatic changes in diabetic coma. Diabetologia 21: 172-177

3. Juhan-Vague I, Vague $\mathrm{P}$, Poisson C, Aillaud MF, Mendez C, Collen D (1984) Effect of 24 hours of normoglycaemia on tissue-type plasminogen activator plasma levels in insulin-dependent diabetes. Thromb Haemost 51: 97-98

4. Frier BM (1986) Hypoglycaemia and diabetes. Diab Med 3: 513-525 
5. Trovati M, Anfossi G, Cavalot F, Vitali S, Masuco P, Mularoni E, Schinco P, Tamponi G, Emanuelli G (1986) Studies on mechanisms involved in hypoglycemia-induced platelet activation. Diabetes 35: 818-825

6. Hutton RA, Mikhailidis D, Dormandy KM, Ginsburg J (1979) Platelet aggregation studies during transient hypoglycaemia. A potential method for evaluating platelet function. J Clin Pathol 32: 434-438

7. Corrall RJM, Webber RG, Frier BM (1980) Increase in coagulation Factor VIII activity in man following acute hypoglycaemia: mediation via an adrenergic mechanism. $\mathrm{Br} \mathrm{J}$ Haematol 44: 301-305

8. Dalsgaard-Nielsen J, Madsbad S, Hilsted J (1982) Changes in platelet function, blood coagulation and fibrinolysis during insulininduced hypoglycaemia in juvenile diabetics and normal subjects. Thromb Haemost 47: 254-258

9. Althoff PH, Rosak C, Ziemen M, Faßbinder W, Breddin K, Schöffling K (1986) Hypoglykämieinduzierte Hyperkoagualabilität - ein Risikofaktor für akute und chronische kardiovaskuläre Komplikationen bei Diabetikern. Akt Endokr Stoffw 7: 70

10. Hedlin AM (1973) Insulin and blood fibrinolytic activity. Thromb Diathes Haemorrh 29: 293-299

11. Hilsted J, Madsbad S, Dalsgaard-Nielsen J, Krarup T, Sestoft L, Gormsen J (1980) Hypoglycemia and hemostatic parameters in juvenile-onset diabetes. Diab Care 3: 675-678

12. Small M, Peterson KR, Flannigan P, Lowe GDO, Forbes CHD, MacCuish AC (1986) Enhancement of fibrinolysis after insulin administration in NIDDM. Diab Care 2: 216-217

13. Vague $\mathrm{P}$, Juhan-Vague I, Aillaud MF, Badier $\mathrm{CH}$, Viard $\mathrm{R}$, Alessi MCH, Collen D (1986) Correlation between blood fibrinolytic activity, plasminogen activator inhibitor level, plasma insulin level, and relative body weight in normal and obese subjects. Metabolism 35: 250-253

14. Fuh MMT, Shieh SM, Wu DA, Chen YDI, Reaven GM (1987) Abnormalities of carbohydrate and lipid metabolism in patients with hypertension. Arch Intern Med 147; 1035-1038

15. Isles C, Lowe GDO, Rankin BM, Forbes CD, Lucie N, Lever AF, Kennedy AC (1984) Abnormal haemostasis and blood viscosity in malignant hypertension. Thromb Haemost 52: 253-255

16. Janka HU, Standl E (1987) Hyperinsulinaemia as a possible risk factor of macrovascular disease in diabetes mellitus. An overview. Diabete Metab 13: 279-282

17. Singer P, Gödicke W, Voigt S, Hajdu I, Weiss M (1985) Postprandial hyperinsulinemia in patients with mild essential hypertension. Hypertension 7: 182-186

18. EASD (1978) The policy of the European Association for the Study of Diabetes on human investigation. Diabetologia 15: 431-432

19. Verdonk CA, Rizza RA, Westland RE; Nelson RL, Gerich JE, Service FJ (1980) Glucose clamping using the Biostator GCIIS. Horm Metab Res 12: 133-135

20. Scharf RE (1986) Thrombozyten und Mikrozirkulationsstörungen. Klinische und experimentelle Untersuchungen zum Sekretionsverhalten und Arachidonsäurestoffwechsel der Blutplättchen. Schattauer, Stuttgart
21. Scharf RE, Tsamaloukas A, Schneider W (1984) Inhibition of platelet alpha-granule release in vitro by forskolin. Thromb Res 33: 661-664

22. Clauss A (1957) Gerinnungsphysiologische Schnellmethode zur Bestimmung des Fibrinogens. Acta Haematol 17: 237-246

23. Breckenridge RT, Ratnoff OD (1962) Studies on the nature of the circulatory anticoagulant directed against the antihaemophilic factor: with notes on an assay for antihaemophilic factor. Blood 20: $137-149$

24. Rosove MH, Hocking WC, Harwig SSL, Perloff JK (1983) Studies of $\beta$-thromboglobulin, platelet factor 4 , and fibrino-peptide $\mathrm{A}$ in erythrocytosis due to cyanotic congenital heart disease. Thromb Res 29: 225-235

25. Löbermann H, Kolde HJ, Deubel R, Peter R, Tourte E, Becker U (1986) Determination of Protein C in plasma. Behring Inst Mitt 79: $112-120$

26. Abildgaard U, Lie M, Ødergård OR (1977) Antithrombin (heparin cofactor) assay with "new" chromogenic substrates (S-2238 and Chromozym TH). Thromb Res 11: 549-553

27. Gram J, Jespersen $J$ (1985) A functional plasminogen assay utilizing the potentiating effect of fibrinogen to correct for the overestimation of plasminogen in pathological plasma samples. Thromb Haemostas 53: 255-259

28. Teger-Nilsson AC, Friberger P, Gyzander E (1977) Determination of a new rapid plasmin inhibitor in human blood by means of a plasmin specific tripeptide substrate. Scand J Clin Lab Invest 37: 403-409

29. Kemmer FW, Bisping R, Steingrüber HJ, Baar H, Hardtmann F, Schlaghecke R, Berger M (1986) Psychological stress and metabolic control in patients with type I diabetes mellitus. $\mathrm{N}$ Engl J Med 314: 1078-1084

30. Nurjhan N, Campbell PJ, Kennedy FP, Miles JM, Gerich JE (1986) Insulin dose-response characteristics for suppression of glycerol release and conversion to glucose in humans. Diabetes 35: 1326-1331

31. Small M, Douglas JT, Lowe GDO, MacCuish AC, Forbes CD (1986) Effect of insulin therapy on coagulation and platelet function in type II (Non-insulin-Dependent) diabetes mellitus. Haemostasis 16: 417-423

32. Kishikawa $H$, Takeda $H$, Kiyota $S$, Sakakida M, Furushima $H$, Ichinose $\mathrm{K}$, Matsuda H, Nakamura N, Uzawa H. Role of $\alpha_{2}-$ adrenergic receptor in platelet activation during insulin-induced hypoglycemia in normal subjects. Diabetes $36: 407-412$

Received: 3 February 1989

and in revised form: 8 May 1989

Prof. M. Berger

Abteilung für Stoffwechsel und Ernährung

Medizinische Klinik der Heinrich-Heine-Universität

Moorenstraße 5

D-4000 Düsseldorf 1

FRG 